\title{
Iowa Celebrates the Centennial of American Independence
}

\section{Homer L. Calkin}

\author{
"HURRAH FOR THE CENTENNIAL!" was the enthusiastic \\ greeting that the Dubuque Daily Times had for the new year of \\ 1876. The Burlington Hawk-Eye echoed this sentiment, "All hail, \\ centennial year!"
}

The editor of the Times (January 1, 1876) commented editorially:

It is well that all of us recall the great events of our history. It is proper that we review the past and scan the present as the indices of the broad and beckoning future. All may rejoice in the grand opportunities afforded us; as the citizens of the best Government on earth; as the glad inheritors of a country free, enlightened, prosperous, one and indivisible.

Likewise, the Hawk-Eye, in an editorial entitled "1876," had this to say on January 1:

As a Nation we enter, today, upon one of the most interesting and memorable years that will probably be seen by the present generation. It is the centennial year, the ' 76 of the second century of our National existence. . . .

To-day ushers in a year that will be full of precious and patriotic memories. We are to have in Philadelphia . . . a great exposition that in many things will illustrate the beginnings, the growth, and the present conditions of these United States. ... .

It will be a cold heart and a dull mind that will not be aroused to patriotic fervor during this memorable year. . . .

We cannot doubt that the best results will flow from the celebrations of this Centennial year. That the great industries of the country will be quickened, that our human sympathies will be broadened and deepened; and that our national life will be strengthened and purified by the associations of the year, and the freshened memories of the past. ...

Three days later the Hawk-Eye was proclaiming that "the Centennial has a good start in all quarters of the union." It 
was hoped that the celebrations during the year would bring "the patriotism of the whole country up to a fever heat, dissolving and sending off on a relentless wave all sectional bitterness, hatred, and strife, and bringing in the reign of universal friendship and good feeling."

Preparations for Iowa's participation in the Centennial Exhibition at Philadelphia had already been underway for several months. Iowans had also been observing the Centennial in other ways for some time. In 1872 the Methodist Episcopal Church passed resolutions that each annual conference of the Church, in its meeting prior to July 4, 1876, should have a "memorial discourse" in recognition of the national centenary. In addition, members of the Church were expected to contribute, "according to the measures of their ability," to the promotion of the welfare of the United States through the cause of education. ${ }^{1}$

When the Upper Iowa Conference met at Dubuque in September 1875, Rev. A. J. Kynett of Philadelphia preached the Independence Centennial sermon. ${ }^{2}$ His central theme was that "a nation can live and prosper only as it is obedient to and co-operates with the will of God." In the course of his sermon, Kynett asked:

Who believes that a century is the limit of our national life? or two, or three, or five? On the other hand, we must not feel too confident that as a nation we are to be immortal. . . . We trust that our nation shall be the Methuselah among the nations of the earth.

The Upper Iowa Annual Conference also carried out the second General Conference recommendation by voting to take up a centennial collection for educational institutions. The Des Moines Annual Conference of the Methodist Church, meeting in Indianola on October 10,1875, took a similar action: an increase was recommended in the endowment for Simpson College.

An activity in a lighter vein occurred on November 25, 1875, when a "Centennial taffy" was held at the home of William Ankeny on the east side of Des Moines. The game was to pull the taffy once for each year of the 100 years and one to "go out."

'Journal of the General Conference of the Methodist Episcopal Church, 1872, 389-90.

${ }^{2}$ Alpha J. Kynett had been a member of the Upper Iowa Conference until he became corresponding secretary of the Methodist Church Extension Society in Philadelphia in 1867. 
After 101 pulls the candy was in "good condition for food, fun and tricks." When the party ended, the wish was expressed that all could meet "in the same place at the second Centennial, and pull candy in the same old style." ${ }_{3}$

A month later a more serious suggestion was made, which, if adopted, "will greatly add to the permanent value of the Centennial." It was proposed that someone in each county should deliver an address on the 4th of July "tracing the history of that particular community during the past century or from the time when it was settled." "As we will see, this anticipated action by the United States Congress and Governor S. J. Kirkwood.

Early in 1876 a number of Iowa towns began to talk of celebrations on the Fourth. Marshalltown was taking steps for a "rousing celebration." ${ }_{5}$ The mayor of Dubuque called for a public mass meeting of patriotic Dubuquers to consider plans for a proper observance. The editor of the Dubuque Times noted on January 27 that "the Centennial will soon be in full blast. We mention this because we would be ashamed to go to press once without saying something about the Centennial." ${ }^{6}$ The next day the celebration committee met and appointed subcommittees to start work on plans.

The Iowa State Daily Register (January 4, 1876) asked, "Will Des Moines have a Centennial Fourth of July celebration?" To those who suggested it was too early to discuss plans for a celebration, the Register said that Des Moines had waited in the past until arrangements were made for twenty celebrations in neighboring towns.

On the 4th of July, for most of the last ten years, our city has been quieter than on Sundays. . . . What we want is 40,000 people here and not 5,000 sent away on the 4 th of July. . . . Let us commence early, organize thoroughly, raise the necessary funds, invite the old soldiers to this reunion, perfect our plans, obtain our speakers, and select such committees to carry out plans as will secure such a celebration here that Des Moines can brag on her Centennial 4th of July celebration for years to come.

In Burlington it was "generally understood that Burlington is to celebrate the approaching Fourth of July in a manner befitting

${ }^{3}$ Iowa State Daily Register (Des Moines), November 27, 1875.

${ }^{4}$ Register, December 21, 1875.

${ }^{5}$ Register, January 28, 1876.

${ }^{6}$ Dubuque Times, January 27, 1876. 


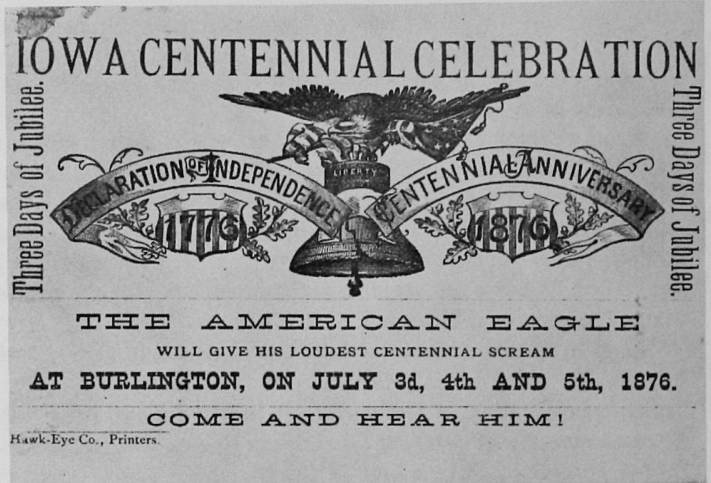

Courtesy Iowa Historical Department, Division of State Historical Society

From the inside front cover of the Orders of the Iowa State University Battalion, 1874-79.

her position and importance, the centennial character of the day and the worthy precedent she has already established." The citizens were urged on January 18 to "bestir themselves early." Eight days later, at the call of the president of the Board of Trade, a very large group considered the expediency of a celebration. "The sentiment of the meeting was unanimous and enthusiastic" and showed "a desire to make this celebration eclipse all of Burlington's best efforts in times past."

As the year progressed, various Centennial activities were held. These ranged from gala entertainments to community improvement projects; from sporting events to religious observances; and from the support of some worthy cause to patriotic celebrations. For instance, in Dubuque the ladies held a "Centennial Masquerade" in February. In Des Moines the Centennial play, "Ocean to Ocean," opened at the Opera House on May 9. The Des Moines fire department planned a parade and ball, "the gayest and grandest they have ever given," for June $5 .{ }^{8} \mathrm{~L} . \mathrm{H}$. Bush and others inaugurated a project of "Centennial Paving" by

${ }^{\prime}$ Burlington Hawk-Eye, January 27, 1876.

${ }^{8}$ Dubuque Times, February 2, 1876; Register, May 7, 10, 1876. 
macadamizing 4th Street from Chestnut to Sycamore Streets in Des Moines.

The Presbyterian Sunday Schools of the west side of Des Moines observed the Centennial year by setting aside a day for "adorning the church yard grounds." On April 29 the entire Sunday School was present to plant thirty-eight trees and plants, including weeping willows, American and Norway spruce, white pines, elms, maples, snowballs, wisteria, honeysuckle and ferns.

George Washington's birthday was emphasized in Iowa during 1876, more than any previous year. The ladies of the Congregational Society of Charles City had a Centennial tea party on February 22 that "was really a grand affair." People thronged Bearup's Hotel from top to bottom, one of the "jolliest crowds that has assembled since the flood." George Washington was the brightest star of the evening. The rooms were filled with the "spirits of '76," in elegant and appropriate costumes.

There was general festivity elsewhere during Washington's birthday. The General Assembly adjourned for a few days and, on February 22, went on an excursion to Ames. There they were entertained by President Welch and the faculty of Iowa State Agricultural College. The Sarsfield Guards, the Fire Department and other civic organizations held balls.

The biggest event in Des Moines during the early part of the year was the Martha Washington Tea Party held on the eve of the first president's birthday. The various churches assisted in the entertainment which was given in Turner Hall in the interest of the free reading rooms of the city. Ladies and gentlemen were to come dressed in the style of 1776 . Everything was to be done to make it an evening of "old-time hospitality and enjoyment." One feature was the election of a George Washington. The candidates were W. E. Andrews, editor of the Des Moines Leader, and C. S. Wilson, editor of the Des Moines Register. Voters paid $\$ 5.00$ each for the privilege of casting their ballots. Wilson wrote of his opponent that Andrews was the favorite candidate, bearing a striking resemblance to Washington and being frequently mistaken for him. "In every instance the mistake has been discovered as soon as he commenced to speak-George always told the

${ }^{9}$ Dubuque Times, February 25, 1876. 
truth." In spite of this, or perhaps because of it, Andrews was elected.

Several hundred people paid the admission fee of ten cents and fifty cents for the supper, which was abundant and excellent, served by ladies in costumes. The young ladies of Des Moines "never fail to appear bewitching in any costume, but in that of a century ago they are the admirable and stately maids of the revolution," reported the Register. ${ }^{10}$

During the Centennial year the Baptists of Iowa, and especially Des Moines, were determined to renew their educational institutions and infuse new life and vigor into them. For this purpose a convention was called in March. Prior to the convention, the board of trustees of the University of Des Moines, a Baptist institution, met and decided to build up the school's endowment. Several hundred dollars were given at this meeting, and the ball was set rolling at the convention for a large campaign throughout the states.

In Pella a meeting of the Baptist ladies resulted in the organization of the Ladies' Central Centennial Association. Its object was to raise funds to endow a "Centennial Ladies Professorship" at Central College, a Baptist school, and educate worthy young ladies in that college. A five dollar greenback would make a person a member of the Association. Canvassers expected to double the college endowment during the Centennial year.

To help raise funds the ladies of the First Baptist Church of Des Moines planned a tea party for April 17 and 18, the "grandest . . . yet given in this State or in the West." Thirteen booths, each bearing the name of one of the original states and decorated in red, white and blue, provided a charming place for two couples to sit and enjoy tea. A young'lady, representing the wife of some Revolutionary leader, presided over each booth which was tastefully and elegantly fitted "with century or more old-china," silver teapots, candlesticks and other articles. The audience room of the church was nearly filled by 8:00 p.m., and the people were treated to a half dozen tableaux, "which richly recompensed them for attending." These scenes included "Taking the Oath," "Writing the Declaration of Independence," "Goddess of Liberty," and

${ }^{10}$ Register, February 17, 19, 20, 22, 1876. 
"the tableaux of the evening 'The Reception of George Washington." ",

The ladies of the Centenary Methodist Episcopal Church in Des Moines gave their Centennial sociable on June 27. George Washington, Thomas Jefferson, their ladies and others were scheduled to wait on tables and serve ice cream, raspberries, cakes and candies. The proceeds were to be applied on the subscription of the Ladies' Mite Society toward liquidating the church debt.

Young people of.Iowa also took an interest in the Centennial. About forty pupils of School No. 10 in the Third Ward in Des Moines wrote seventy chapters of a book about school life and customs in 1876. In the preface they noted that through the press, by Martha Washington tea parties and centennial plays, songs, pictures and stories they had learned how their forefathers had lived, dressed, talked and acted. "But we hear nothing about the school children . . . we look in vain for an old representative of a 1776 School Marm, with the habitual weary look on her face, and the rod of power in her hand." The book was to be sent to Philadelphia to the Centennial Exhibition and

then presented to our worthy teacher to be carefully kept and left to someone who will faithfully promise to send it to Des Moines in 1976, to be shown to the boys and girls of that time, so they may see what those, whose places they fill, left as a memento of school life in 1876. ${ }^{11}$

The pupils of Des Moines were not the only Iowans who became active in writing history in 1876. On March 13 the United States Congress, by Joint Resolution, recommended that each county or town have a historical sketch read during the celebration of the Centennial anniversary of American Independence. The Congress further recommended that a copy be filed in the clerk's office in each county and a copy sent to the Library of Congress so that "a complete record may thus be obtained of the progress of our institutions during the First Centennial of their existence." Governor Samuel J. Kirkwood endorsed this resolution on May 11. He thought Iowa was "very happily situated to carry out its [the Resolution's] object. Our history, eventful as it has been, can be told by men who have witnessed it all, and indeed helped to make it." He suggested that narratives of the several

"Register, April 28, 1876. 
counties, townships, cities and towns be prepared and read. Afterwards, one copy should be sent each to the Library of Congress, the State Library in Des Moines, the State Historical Society in Iowa City and the auditor of each county. ${ }^{12}$

Kirkwood thought the information in these histories could be materially augmented with other sketches. These could include school districts; colleges, academies and other private institutions of learning; church organizations; missionary, benevolent, literary, scientific and fraternal associations; agricultural progress, including state and county societies; manufacturing interests; mining interests; mercantile interests; and the several professions - "in short . . . all enterprises or occupations whose history may in any manner illustrate the development of the resources of the State, its past progress, and its present condition." ${ }^{13}$

In line with the governor's proclamation, C. W. Slagle of Fairfield suggested a prize for the best county history. He proposed $\$ 100$, raised by $\$ 5$ contributions. The Register added $\$ 10$ to Slagle's \$5.

Many celebration committees did appoint a historian whose sketch was read during the program on the Fourth. These histories ranged in length from a history of less than 2,000 words for Grant Township in Lyon County to a 35-page printed history of Jefferson County. In the latter case, the citizens of the county met at Fairfield on May 26, 1876, to select a committee to procure funds for the publication of such a history. The board of Supervisors appropriated $\$ 300$ to meet the costs of publishing. Major Charles $\mathrm{H}$. Fletcher was chosen to be the historian. ${ }^{14}$

The Centennial of American Independence was no different than other centennial observances, such as that of the Civil War a few years ago. The Centennial was commercialized by some with

${ }^{12}$ Records of the Library of Congress show that eleven histories from Iowa were deposited there. These were from the counties of Cass, Jefferson, Lyon, Page, Story and Woodbury; Grant Township, Lyon Co.; and the towns of De Soto, Keota, Miongana, and Shenandoah. U.S. Library of Congress, A Compilation of the Centennial Celebration and Orations deposited with the Librarian of Congress in response to the Joint Resolution of Congress, approved, March 13, 1876.

${ }^{13}$ Messages and Proclamations of the Governors of Iowa, edited by Benjamin F. Shambaugh, IV (Iowa City, 1903-1905), 310-12.

${ }^{14}$ Charles H. Fletcher, Jefferson County Centennial History, (Fairfield, 1876), 2. 
numerous companies, organizations and others appropriating the word "Centennial" to advertise or publicize some product or enterprise. For instance, the Des Moines Register carried advertisements for "Centennial stove polish ... the best polish in the world made from pure plumbago." Centennial collars and cuffs were on sale at Knight's store in Des Moines. At Iowa City a "Centennial bridge" was to span the Iowa River at the site of the pioneer ferry and the first bridge that ever crossed the Iowa River.

Lyons was to have a large, new hotel in 1876 to be called the "Centennial," while George Badke named his new saloon on Iowa Street in Dubuque "The Centennial." In Dubuque we also find that a large number of the "most promising young men" formed the "Centennial Debating Club," and the boys on the 11th Street hill organized a "Centennial Foot Ball Club." ${ }^{15}$

The Register editorialized:

Here in America we never do anything on the halfshell. This is the country where we 'go the whole hog.' Just now everything is Centennial. Preachers preach about it; lawyers shout about it; small boys yell about it, and whole families think about it. All the dry goods [stores] are full of it.

There were Centennial silks, satins, and socks; "Centennial backcombs" and "Liberty-bell snuff boxes."

There are Centennial cigars and Centennial matches with which to light them; Centennial boots to cover hundred year old corns; Centennial hats and Centennial corsets. In short, we have run wild over the fact that the nation set up business for itself a century ago. ${ }^{16}$

Greatest attention, however, was given to the Fourth of July celebrations during the Centennial year. Many towns, both large and small, throughout the state observed the anniversary of American Independence in some manner. People began as early as January to discuss the forthcoming festivities, but in the months to follow many cities were to go through periods of uncertainty and indecision before final plans were made and carried out.

For instance, in Dubuque a large number of citizens met in February and agreed that a celebration should be held. But, dif-

${ }^{15}$ The editor of the Dubuque Times (May 4, 1876) wrote "This is the time of centennialness in everything. Centennial kisses are now the go, but it takes an hour by the clock to execute one."

${ }^{16}$ Register, May $11,1876$. 
ferences arose, and Col. D. E. Lyon, chairman of the meeting, called for harmony and the smothering of ill-feelings. In announcing a meeting three days later, he urged, "Let us dwell together in peace. Let harmony and good order be the rule. Let us lay solid the foundation for the commemoration of our 100th anniversary." 17

The Times noted after this second meeting that Dubuque's 4th was "slowly recovering from a severe attack of croup and bids fair to come out soon fully restored to health." If this were true, Dubuque would have a celebration "that will knock the breath out of all previous demonstrations in the history of this metropolis." Evidently the program committee made little progress, though, as the Times was telling its readers the next month, "Let us lay off our overcoats and talk up the celebration again." On April 7 the Times asked "What has become of the 4th of July committee of ' 76 ? Who, what and where is it, and what is it or they doing or going to do?"

The people of Council Bluffs were able to get started easier than in some towns. The initial meeting to organize was held on February 5. Within two weeks the Nonpareil was claiming that "a bigger Fourth than the one in contemplation will not be held on the Slope again in fifty years at least, and let there be no mistake." The money was raised as early as February, and prospects for a great day were favorable, the people being "able and willing." Following this first burst of enthusiasm, things began to slow down. Finally, by the end of May the Nonpareil reported that the committee was "aroused from their lethargy, and will make themselves collectively felt."

Near the end of March the editor of the Des Moines Register thought it was about time that the business men of the city act on plans for the Fourth. While other cities were organizing and raising money, "we are absolutely doing nothing. We cannot wait till the last moment." If nothing was done soon, small celebrations would be started in all of the towns within thirty miles. Now most of these towns would gladly join in a large celebration. On April 11 a meeting was held at which a committee of twenty-five was appointed with full power to proceed and make all necessary arrangements. Committees were named to handle various aspects

${ }^{17}$ Dubuque Times, February 8, 10, 1876. 
of the celebration-from finance to vocal music, fireworks to invitations. W. M. Skinner, addressing the meeting, said that Des Moines offers

you an opportunity to rekindle your patriotism by uniting in a celebration of the glories of that event. . . . We shall be looking over the heritage bequeathed to us to gain strength and virtue in the contemplation of the privileges, the institutions and the present and prospective advantages of our common country.

Come, then, and unite with us in hallelujahs for the blessings and privileges, and honors conferred by an Almighty. Power through the men and women of 1776 .

Let us make a demonstration worthy of the occasion, and so impress upon our hearts and the hearts of the rising generation, the memories of the past and the glories of the present, that all internal difficulties and strife will be forever banished from the land.

This address was adopted as the circular of invitation to be sent to all neighboring towns and cities.

Three reasons were given for aiding and encouraging a Centennial 4th in Des Moines. First, it would be the 100th anniversary of national existence. "The Capital City of this grand new western state cannot afford to have its military, fire organization, bands, etc., go to other cities . . . to celebrate so marked a day in our national history. Second, 16,000 people from Des Moines and thousands of neighbors could not go to Philadelphia to the Centennial Exhibition. And third, American citizenship was composed of the nationalities of the world. "If there ever was a day to be celebrated, to cement people together . . . and help teach all the spirit and patriotism of our common forefathers, the patriots of 1776 , it is the 4th of July." ${ }^{18}$

Not all towns were having troubles getting started. Pella announced in March that it had plans to order "fire-works by the ship load, direct from China." Nearly every town of any size and importance made arrangements for impressive celebrations. Orations, gun salutes, parades, decorated business establishments, and fireworks were common in many towns and cities.

In prior years Fourths of July in Decorah had "been rather slim affairs." In 1876 the people "did their best, and the celebration was a great success," from ushering in the day with the firing of thirteen guns, to a torchlight parade in the evening.

Newton's celebration began with a Soldiers' Reunion on Mon-

${ }^{18}$ Register, May 18, 1876. 
day, the third. Inclement weather on the Fourth did not prevent successful celebration. In Oskaloosa, however, festivities were "somewhat dampened by the storm," and a large portion of the program was dispensed with because of mud.

Prairie City started the day with the usual salute, followed at ten by a procession of "Masqueraders," a "goodly company" on horseback with some "very nice" costumes. After dinner there were greased pole, sack and potato races.

The 4th dawned cloudy, with much fog, in Charles City, and the rain fell at intervals throughout the day. By noon the largest crowd ever in Charles City had gathered in spite of the weather to see a parade in which there were 350 teams. Perry was equally jammed as farmers from the surrounding country came pouring into town for a day that included a parade, orations, toasts and a dinner by the Perry ladies.

Some towns tried to add something a bit different. Malvern offered bushels of peanuts, Creston an immense barbecue with an ox roasted whole, and Neola a basket dinner. Shenandoah had a greased pig and soaped pole, "just for fun, you know."

The report from Waterloo was that the celebration was "a success far exceeding general expectations." The day was excellent except for "very thin mud everywhere." Throughout the day "the heavens were in the sulks and threatened to interfere, and did get up a most successful competition with our Centennial exhibition of fire-works."

Colonel C. H. Gatch of Des Moines was the principal orator at Dexter. He expressed thanks that the sun would not "behold in all the land a single sighing slave panting for freedom." Never again would "loud hosannas for freedom" on the Fourth mingle with the "clanking chains of three millions." In looking to the future, Gatch saw the United States entering upon its mission to "the oppressed and down-trodden of all nations. Hope will radiate . . . to the darkest corners of the earth, reviving the fainting hearts of the millions yet in bondage." He called upon his listeners to "endeavor so to acquit ourselves in all the relations of life, so that each one of us shall contribute somewhat to its [America's] brightness." 19

Not every town had a safe and sane Fourth. Early in the

${ }^{19}$ Register, July 8, 1876. 
morning the boys in Polk City placed cannons in the public square and began to fire them. On the seventh round, one burst scattered pieces in all directions. One piece weighing twenty pounds passed through Mr. Kuntz's store, making an eight by sixteen inch hole. Johnnie Clark, who touched it off, was thrown about five feet in the air by the concussion which was heard ten miles away.

In Council Bluffs the booming of artillery and the pealing of bells at sunrise heralded the start of the historic day. At ten o'clock the parade formed on Broadway. The fire department, the Council Bluffs Light Artillery, the St. Patrick Benevolent Society and the Butchers' Union, in uniform and mounted, made up the procession and moved through the principal streets. After the exercises in the park, a few people retired to the quiet of their homes while hundreds stopped to refresh themselves with a dinner served by the ladies of the Baptist Church. The prisoners in the Pottawattamie County jail had a keg of choice lager, furnished by Jailer Hickey, along with their usual food.

In Dubuque the weather was propitious and by the time of the parade, the sidewalks and streets around the city square were "almost paved with people." Dubuque "crowned herself with honor" with a parade that "passed like a panorama"-police, cavalry, the fire department, pretty girls, civic organizations, "cars of state," Indians, mounted Knights Templar and other features. At the Tivoli Garden J. H. Shields, the orator of the day, gave a "tribute to republican principles and the true men, and brave, who declared, established and maintained them." Shields did not see any hopes for the permanent success of "free representative republican institutions" outside the limits of the United States. Yet, the example of the United States had and would continue to have "a most salutary and benign influence on the liberties and privileges and every people and in every clime."

Shields, along with countless others, felt that the future of America rested on the virtue and intelligence of the people. The danger was not from without. He concluded.:

When men high in position, trusted by the people, would rather be the chiefs of a party, than the friends of their country, when the dark day comes that men get power and position, because they are corrupt and profligate, and the wise and good are banished from the halls of legislation, the judgment seat, and the high posts of honor and duty, because they dare to be honest, then may we despair of the republic-the steps of 
its decline will soon be numbered-it will even then have reached the very threshold of that common sepulchre of republics, whose inscription is, nulla vestigia retrorsum.

If we are but true to ourselves, the enjoyment of liberty, property, religion, and independence, will be transmitted to the latest posterity. ${ }^{20}$

The two most extensive celebrations for the Centennial ' 76 in Iowa were those in Burlington and Des Moines. Burlington was described as a

city of bunting: a brick and mortar forest that blossomed out in the colors of the rainbow: that sent forth great tendrils of tri-color festoons and clusters of fluttering flags and sprays of graceful streamers: a patriotic wilderness.

Flags were everywhere. Even wagons and dump carts were moving flagstaffs. A grand arch of welcome, trimmed with flags, evergreens and forest boughs, greeted those who arrived by rail. On the side facing the depot was the greeting "Welcome" and beneath it "17-18-76." On the opposite side was "Come often, 1876." A monument modeled after the Bunker Hill monument was on Main Street under the center of three arches. After darkness fell, the shaft of the monument was aglow with the brilliant rays of hundreds of gas jets that outlined it. Other arches were placed at a number of the principal intersections.

Every one, rich and poor, vied to make his private display attractive. As a result, business houses and private homes alike were decorated so lavishly that Burlington was "a sea, a mass, a waving, moving, flaunting, floating sea of red, white and blue." The three-day celebration opened at sunrise on Monday, July 3, with a thirteen gun salute-one for each of the thirteen original states. At 8:00 a.m. an instrumental concert was given in the Grand Pavilion which had various appropriate designs and mottoes on it. On the south side one could read the words, "One country and one flag"; on the west, "Our State. The river, its artery; the railroads, its sinews; this city, its heart"; and on the north, the motto, "We know no North, South, East or West."

Monday was Firemen's Day. Marshal Thomas Duncan, on a spirited white horse, led the procession of fire equipment and bands. The fire departments of at least nine cities showed off their

${ }^{20}$ Dubuque Times, July 7, 1876. 
equipment and bright uniforms. ${ }^{21}$ The men from Galesburg were dressed in bright red shirts with blue collars and cuffs and black pants. Those from Fort Madison wore light blue shirts with red braid, black belts with showy yellow trimmings and blue cloth caps. The Vinton fire company wore dark blue jackets with wide collars of white leather and cuffs faced with the same material, white belts and blue slouch hats with silver ornaments. Equipment was polished until the brass gleamed like gold.

In the afternoon the firemen competed in a tournament in which prizes were given for the best hand fire engine, the best chemical fire engine, the best hose company and the best hook and ladder company. At 8:00 p.m. the firemen were in a torchlight parade. Throughout the evening, the entire city-businesses, public buildings and private residences-was brilliantly illuminated.

The Fourth was ushered in at sunrise with the ringing of all the bells in the city. The day did not really dawn. It just started with "lowering frowning clouds" which warned of a possible continuation of the disagreeable weather of the previous evening. However, long before ten in the morning, anyone who wanted to make any progress through the crowded streets left the sidewalks and took to the middle of the street. The grand parade consisted of three divisions: military and civic organizations; trades; and mechanical. The business displays in the parade included a "unique and attractive" display of carpets, curtains and shades by Greenbaum, Schroder \& Co.; an immense glove and umbrella by Washburn's; and a furniture display by Lewis and Franklin.

At noon a Centennial salute of one hundred guns, representing the century since Independence, was fired. In the afternoon the people assembled in a mass meeting at the Grand pavilion. The Hon. John H. Gear, president of the day, delivered the oration. In part he said:

One hundred years ago one bell rang out the glad tidings on the summer air, 'Proclaim liberty throughout all the land to all the inhabitants thereof.' Today as we stand on the threshold of the second century of the nation's existence, bells in every city, village and hamlet throughout this broad land have taken up the refrain of 1776 and proclaim liberty to the generations of the future.

${ }^{21}$ Galesburg, Creston, Keokuk, Fort Madison, Vinton, Quincy, Marion, Red Oak, and Burlington. 
At night Burlington was ablaze with lights. Although rain was falling, the streets were full of people. When the long column of torches moved through the rain, "the enthusiasm knew no bounds." At every corner colored lights burned, and sky rockets and Roman candles darted by the thousands through the air. But the rain came harder and harder so the crowd dispersed for home.

Burlington's third day of celebration started with a thirtyeight gun salute- one for each of the states in the union in 1876 . The sky was cloudless; everyone was able to enjoy the competitive drills among the various military units and the regatta on the river. The celebration came to a close with the city being illuminated from one end to the other and with another torchlight parade. ${ }^{22}$

In Des Moines the committees completed their work as the Fourth drew near. The parade was to be "a New Orleans Mardi Gras on a somewhat smaller scale." Orators were lined up; fireworks purchased; patriotism was at "fire heat"; Gov. S. J. Kirkwood had agreed to be President of the Day; and "everybody is boiling over, with anticipation of the glories of the comeing [sic] Fourth." 23

There was a variety of activities in Des Moines in connection with the Fourth. The Old Settlers Association of Polk County had two Centennial picnics. The Turners held a "grand Centennial Ball.” Howe's Great London Circus, Hippodrome and Menagerie was on exhibit during the afternoon and evening. P. T. Barnum had telegraphed the city that his show was to be used in any practical way possible to make the day a success. Observances were completed with a Solemn High Mass of Thanksgiving at St. Ambrose Church the morning of July 5 in honor of "our hundreth anniversary as a nation, and to implore His blessings for the future-that He may vouchsafe to us a perpetual integrity of our free institutions."

All was completed, ready for the big celebration. The only error in planning was that the place selected for the fireworks was almost inaccessible. Three arches had been erected-one on the east side and two on the west side of the city. The Walnut Street

${ }^{22}$ Burlington Hawk-Eye, June 22, July 2, 4, 6, 1876.

${ }^{23}$ Register, May 6, 24, June 21, 1876. 
arch was inscribed, "The Centennial Anniversary." The sides were covered with banners upon which were painted namesTrenton, Green, Lexington, Washington, Lafayette, Saratoga, etc. From the main arch two oval four by six foot pictures of Washington and Franklin were suspended. Joseph Sharman was responsible for the portraits which "were true to life and show true genius as an artist. They were very attractive features of the decoration and the admiration of the crowd." The arch was trimmed with evergreens, oak leaves and the national colors. A facsimile of the Liberty Bell hung from the center of the arch.

The Court Avenue arch bore signs, "Welcome" and "United we Stand, Divided we Fall." Banners with historic names decorated the various sides. Upon each side there was a large national shield with 1776 and 1876 painted on it. Pictures of Patrick Henry and Lafayette hung from this arch. On the top of the arch had been placed a full sized American eagle with the national colors in its talons.

A whistle, connected with the steam boiler of the Register, was placed in the beak of the eagle. At midnight on July 3 the whistle ushered in the anniversary of independence "with screams such as would frighten the proud bird of freedom, should it wing this way." The steam whistle in the eagle's mouth was blown for the first hour of the new century of independence, ably seconded by the railroads.

At sunrise the 4th was ushered in with the ringing of bells and the firing of artillery. Long before daylight "the streets were full of people and by sunrise their number had increased to an army." By the time of the parade at least 40,000 lined the streets of Des Moines. Some thought this would probably have been doubled except for the storm the day before. The parade was called "the grandest spectacle ever seen in Iowa." The procession was nearly three miles in length. The parade was to illustrate the "wonderful growth and prosperity of Iowa-showing the promise of her future wealth." The editor of the Register asked the relevant question: "If $\mathbf{4 0}$ years show such wonderful advance, what will [Iowa] be at the second Centennial?"

At the head of the parade was "Iowa in 1776." There was a representation of unbroken sod with three live young wolves playing, "showing ... the unbroken prairie wilderness of Iowa a hundred years ago." This was followed by a car (or float as it 
would be called today) bearing a wigwam on the edge of the woods with several Indians in "full savage attire." The next section showed Iowa in 1830. A newly raised cabin of the pioneer settler, a mere shell of a house, was in the center of the car. Outside, a white man and an Indian were seated, cooking the evening meal, while the plow and harness were nearby, idle after a day's work of breaking the virgin prairie. Following this was an immense banner. One side bore a great shield with the Iowa coat of arms. On the other were painted statistics on acres in cultivation; miles of fence; bushels of corn, wheat, oats, rye and other grains; livestock; and other Iowa products. On the reverse side appeared "Population in 1836-10,000" and "Population in 1876 $-1,400,000 . "$

The Goddess of Liberty and Columbia, dressed in white sheen veils, occupied the beautiful dragon chariot of Howe's Circus drawn by eight ponies. They were escorted by thirteen little girls dressed in the national colors and wearing a golden crown with one of the names of the thirteen states. They rode in the "looking glass car" from the circus, "a magnificent structure, all glittering with gold and ornament," and drawn by four horses.

George Washington and his bodyguard of twenty-four, dressed in "full Continental uniform and mounted," was also in the procession. The 3rd Regiment of Iowa Militia presented a "fine military pageant." The Navy had three large gunboats on wheels, in which there were guns and mortars, manned by men in uniform and firing as they went. One of the "grandest pictures" in the parade was the fire department. The firemen were handsome in "their brightest uniforms, and the horses, gayly [sic] caparisoned, looked and stepped as proudly as the boys." The public schools of Des Moines were represented by a school house, complete in every particular, neatly painted white and crowned with a belfry and bell. A youthful "school marm" and scholars were inside.

A number of ethnic and fraternal groups-the Sons of Erin, the German Catholic Society, St. George Society, the Odd Fellows and the Cadedonian Club-marched in the procession in handsome regalia. The car of the Turner Society represented the objectives of that group. There were bars for body strengthening and a library and reading room to show their interest in educat- 


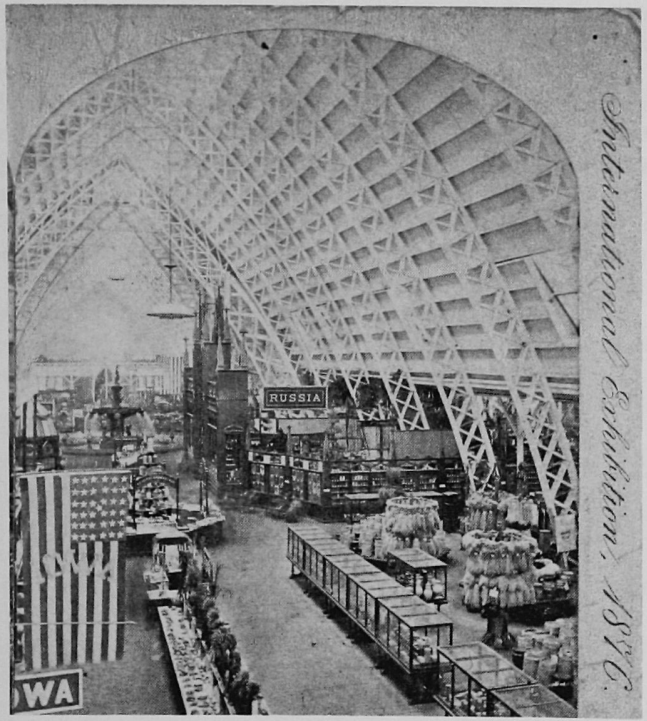

Courtesy Iowa Historical Department, Division of State Historical Society

A view of Agricultural Hall at the International Exhibtion in Philadelpia, 1876. Iowa's display can be seen in the lower lefthand corner.

ing the mind. Businesses and trades were represented in a large number of displays of the parade. The Des Moines State Leader had a car filled with about fifty of its newsboys while the Register had a printing office with men setting type and a press printing as it went.

Brick masons mixed mortar and laid bricks. The carpenters had a carpenter shop on wheels. As the parade progressed, they erected a frame house, sawing, planing, putting on clapboards and performing other tasks. To demonstrate work in the coal mines, a live mule hauled coal underground to the shaft while miners were at work. A steam engine provided power for the looms of the woolen millers. In a shirt factory men and women 
worked at sewing machines making shirts. Mason and Company made tin cups and threw them to the crowd as they were made.

J. H. Windsor and Company, pork packers, had a display with a pen of twelve little pigs at one end and six fat hogs at the other. A pork barrel was in the center of the display. The "Fantastics," a group of about 700 mounted men in costume, brought up the rear of the procession. Included were Mr. Peed's Indians who were "among the most natural presentation of the day." The devils were there, too, with their Hades with them, "the colored flame mounting up from a burning cauldron in their midst."

In the afternoon about 20,000 gathered around the speaker's stand at the fairgrounds to hear the orators, B. F. Montgomery and Dr. E. R. Hutchins. Another 8,000 by actual count were in a show tent at another location.

The location for the fireworks in the evening proved to be as highly unsatisfactory as predicted. Many who gathered to see them soon became disgusted at the distance between them and the display and abandoned the effort. Probably 1500 made the try and enjoyed the scene until the Fourth of July storm started about nine o'clock and put an end to the ceremonies. The storm "raged furiously until nearly midnight. There was a constant and terrifying roll of thunder"; the rain came down in "great sheets and the lightning blazed incessantly." Thus, the great day of celebration ended in Des Moines as it did in many other Iowa towns and villages - in the midst of one of the most furious storms of the summer.

In an editorial the Dubuque Daily Times (July 6, 1876) noted that

the first century of our independence is past-the second is born. . . . This national greatness - this triumph of liberty-this century of growth of national independence is a picture for the people of the earth to admire and draw inspiration from. ...

It will be well for all to reflect upon the future possibilities of the American people in the light of this first hundred years of independence. It may be well to inquire whether this liberty of to-day be as far removed from the true and full liberty yet to come, as was that of a century ago from that we celebrate today. Is there now, as we sing, and shout, dance and jubilate, such genuine independence as fully satisfies the ambition of the American soul? Are there not certain forms of social, religious and political slavery and bigotry which induce restiveness, and which spur us forward toward new declarations of independence? And, who shall say where this aspiration shall stop? Indeed, can it stop? 
Copyright of Annals of Iowa is the property of State of Iowa, by \& through the State Historical Society of Iowa and its content may not be copied or emailed to multiple sites or posted to a listserv without the copyright holder's express written permission. However, users may print, download, or email articles for individual use. 